SGEV

DEC 151925

OSTI
WSRC-TR $=95=0.353$

Revision 0

\title{
A TRANSMISSION ELECTRON MICROSCOPY EVALUATION OF SOLID-STATE UPSET WELDS IN TYPE 304L STAINLESS STEEL (U)
}

\author{
Michael $H$, Tosten
}

\section{SAVANNAH RIVER TECHNOLOGY CENTER}

Publication Date: September 8,1995

Westinghouse Savannah River Company

P. O. Box 616

Aiken, SC 29802

PREPARED FOR THE USS DEPARTMENT OF ENERGY UNDER CONTRACT DE-ACO9-88 PRESENTLY UNDER CONTRACT DE-ACOO9-8\$SR18035

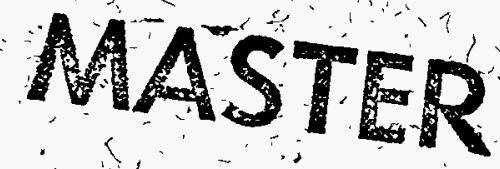

DISTRIBUTION OF THIS DOCUNENT IS UALMARTED, QX 


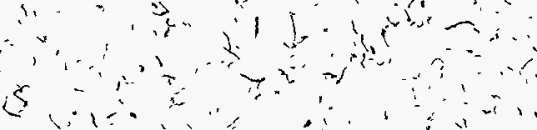

$i$

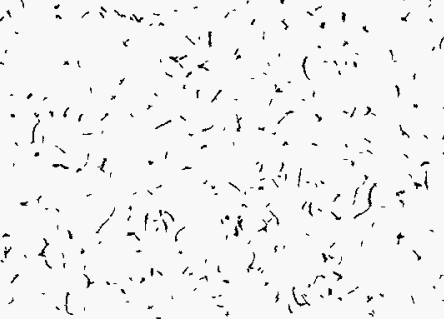

\section{DISCLAAIMER}

This report was prepared as an account of work "sponsored by an agency of the United States Government. Neither the United States Government, nor any agency, thereof, nor any of their emplóyees, makes any warranty, expressed or impliéd, or assumés any legál liability or responsibility for the accuracy, completeness, on usefulness of any information, apparatus, product, or process djscloséd, or represents that its use would 'rot infringe privately owned rights. Réference "herein to 'any' specific 'commercial product, process, or service 'by trade name, trademark, manúfacturer, or otherwise does not necessarily constitute or imply its endorsement, recommendation, or favoring by the United States Government or any agency thereof. The views and opinions of authors expressed herein do nat necessarily state or reflect those of the United States Government or any agency theréf. 
APPLIED SCIENCE \& ENGINEERING TECHNOLOGY

Keywords:

Type 304L Solid-State Welding

Resistance Welding Electron Microscopy Joining

Retention - Permanent

\title{
A TRANSMISSION ELECTRON MICROSCOPY EVALUATION OF SOLID-STATE UPSET WELDS IN TYPE 304L STAINLESS STEEL (U)
}

\author{
Michael H. Tosten .
}

Issued: September 8, 1995

D. Thener- Pentair

Authorized Derivative Classifier

$\frac{10 / 9 / 95}{\text { Date }}$

SRTC SAVANNAH RIVER TECHNOLOGY CENTER, AIKEN, SC 29808

Westinghouse Savannah River Company

Prepared for the U. S. Department of Energy under Contract DE-AC09-8\$\$ SR18035 


\section{TITLE: A TRANSMISSION ELECTRON MICROSCOPY EVALUATION OF SOLID-STATE UPSET WELDS IN TYPE 304L STAINLESS STEEL (U)}

\section{Approvals}

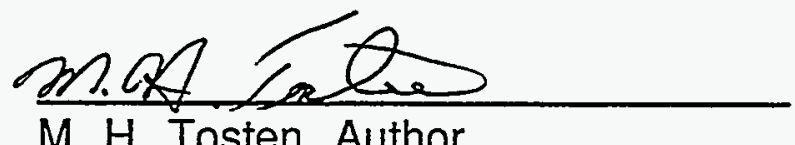

Date: $10 / 5 / 95$

Materials Compatibility and Joining Technology Group

Materials Technology Section

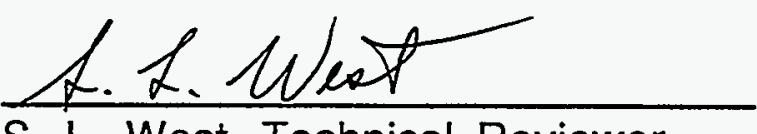

Date: $10 / 5 / 95$.

S. L. West, Technical Reviewer

Materials Compatibility and Joining Technology Group

Materials Technology Section

U, R.

Technical Reviewer

Date: $10 / 5 / 95$

W. R. Kanne, Jr., Technical Reviewer

Materials Compatibility and Joining Technology Group Materials Technology Section

D. Thome Ralini

D. Thomas Rankin, Manager

Materials Compatibility and Joining Technology Group

Materials Technology Section

Date: $10 / 5 / 95$

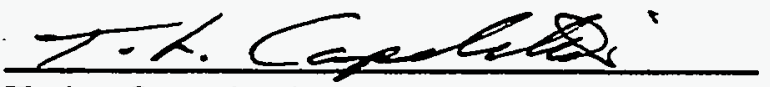

Date: 10/3/55

T. L. Capeletti, Manager

Materials Technology Section 
INTRODUCTION................................................................................... 1

EXPERIMENTAL PROCEDURE.

RESULTS AND DISCUSSION.

UPSET WELDED CYLINDERS..

4

GLEEBLE SAMPLE $\left(1200^{\circ} \mathrm{C}\right)$..

GLEEBLE SAMPLES $\left(800^{\circ} \mathrm{C}\right.$ AND $\left.900^{\circ} \mathrm{C}\right)$

6

ORIGIN OF INTERFACE PRECIPITATES.

7

CONCLUSIONS.

8

FUTURE WORK..

8

ACKNOWLEDGMENTS.

9

REFERENCES.

9

FIGURES. 
1. Schematic diagram illustrating the TEM specimen preparation.

2. Light micrograph showing weld interface and adjacent grain structure in the upset welded cylinders.

3. Subgrain structure immediately adjacent to the weld interface in the upset welded cylinders.

4. Microstructure of the upset welded cylinders at approximately $5 \mathrm{~mm}$ from the weld interface.

5. Weld interface in the upset welded cylinders.

6. Amorphous $\mathrm{Si}, \mathrm{Al}$, and $\mathrm{Mn}$-rich precipitates on the weld interface in the upset welded cylinders.

7. SEM image from an efched, upset welded cylinder sample 16 which shows numerous precipitates on the weld interface.

8. Micro-crystalline precipitate, identified as the spinel $\mathrm{Mn}_{1.5} \mathrm{Cr}_{1.5} \mathrm{O}_{4}$, on the weld interface in the upset welded cylinders.

9. Grain structure immediately adjacent to the interface showing fine grains and faulting $\left(1200^{\circ} \mathrm{C}\right.$ Gleeble sample).

10. Base microstructure at $5 \mathrm{~mm}$ from the weld interface $\left(1200^{\circ} \mathrm{C}\right.$ Gleeble sample).

11. Microstructure near the weld interface $\left(1200^{\circ} \mathrm{C}\right.$ Gleeble sample).

12. Precipitates on the weld interface $\left(1200^{\circ} \mathrm{C}\right.$ Gleeble sample).

13. Si and Ca-containing amorphous precipitates on the weld interface $\left(1200^{\circ} \mathrm{C}\right.$ Gleeble sample). 
14. $\mathrm{Mn}_{1.5} \mathrm{Cr}_{1.5} \mathrm{O}_{4}$ precipitates on the weld interface $\left(1200^{\circ} \mathrm{C} \quad .23\right.$ Gleeble sample).

15. Centered-dark field micrograph of body-centered cubic martensite at the weld interface $\left(1200^{\circ} \mathrm{C}\right.$ Gleeble sample).

16. Hexagonal $\varepsilon$ martensite at $5 \mathrm{~mm}$ from the weld interface 25 $\left(1200^{\circ} \mathrm{C}\right.$ Gleeble sample).

17. $\mathrm{Mn}_{1.5} \mathrm{Cr}_{1.5} \mathrm{O}_{4}$ and amorphous precipitates on the weld interface $\left(900^{\circ} \mathrm{C}\right.$ Gleeble sample).

18. Microstructure of the $800^{\circ} \mathrm{C}$ and $900^{\circ} \mathrm{C}$ Gleeble specimens 27 in the near weld region.

19. Amorphous precipitates located at approximately $250 \mu \mathrm{m} \quad 28$ from the weld interface $\left(800^{\circ} \mathrm{C}\right.$ Gleeble sample). 


\title{
A TRANSMISSION ELECTRON MICROSCOPY EVALUATION OF SOLID-STATE UPSET WELDS IN TYPE 304L STAINLESS STEEL
}

\author{
By \\ Michael H. Tosten
}

\section{SUMMARY}

Transmission electron microscopy (TEM) was used to characterize the microstructures at and near the weld interface in upset welded Type $304 \mathrm{~L}$ stainless steel test samples. Two sample configurations were examined in this study; upset welded cylinders prepared using a commercial resistance welder and cylindrical shaped samples welded in a Gleeble 1500 thermomechanical simulation device. The Gleeble samples evaluated were welded at $800^{\circ} \mathrm{C}, 900^{\circ} \mathrm{C}$ and $1200^{\circ} \mathrm{C}$ with a $0.5 \mathrm{~cm}$ weld upset. The base microstructure of the samples varied with weld temperature. The lower temperature specimens contained a large free-dislocation density and distinct dislocation cells. The higher temperature specimens contained well-developed subgrains and a much lower free-dislocation density. The microstructure of the upset. welded samples most closely resembled the $1200^{\circ} \mathrm{C}$ Gleeble sample. No distinct bond line was observed by TEM in any of the-specimens, i.e., diffusion and grain growth occurred across all weld interfaces. However, weld interfaces in both specimen configurations were characterized by the presence of 50-300 nm diameter particles spaced between 300 and $1300 \mathrm{~nm}$ apart. Through the use of electron diffraction analysis and $\mathrm{X}$-ray microanalysis two precipitate types were identified in both specimen configurations. A crystalline phase very similar to $\mathrm{Mn}_{1.5} \mathrm{Cr}_{1.5} \mathrm{O}_{4}$ and an amorphous phase enriched mainly in $\mathrm{Si}$ and $\mathrm{Al}$ were observed. Surface oxides and/or internal impurities may be sources for these precipitates. Future work will include a controlled study designed to determine the origin of the interface precipitates.

\section{INTRODUCTION}

Solid-state resistance upset welding is being used at the Savannah River Site as an alternative to conventional fusion welding $[1,2]$. Resistance welding is a joining process by which heat is obtained from electrical current passing through the weld joint. Unlike fusion welding essentially no melting takes place and the weld region retains 
many of the characteristics of the base metal. This technique has been used successfully for pinch welding and reclaimation welding of tritium reservoirs and is being considered for use in certain tritium reservoir fabrication applications. Solid-state resistance welding is being used currently to weld the closure "plugs" into DWPF stainless steel waste canisters.

Until now the microstructure of solid-state upset resistance welds has only been analyzed metallographically using light microscopy and scanning electron microscopy. Both of these techniques lack the resolution necessary for fine scale microstructural examination and neither technique is capable of examining the "internal". (non-surface) microstructure of materials.

The need to understand the microstructure(s) at the weld interface is clearly evident given the results of a recently completed study [3] in which the fracture toughness properties of upset welded Type $304 \mathrm{~L}$ stainless steel charged with hydrogen were measured and compared to the as-received and as-welded properties. The results of this study showed that the fracture toughness of the as-welded steel was lower than the as-received steel. The fracture toughness of the welded, hydrogen-charged steels was reduced even further. The degradation in properties of the welded steel (with or without hydrogen) was attributed to the presence of "microscopic precipitates" on the weld plane.

In the current investigation specimens from two sources were analyzed; upset welded cylinders joined using a commercial resistance welder and cylindrical test bars welded with a Gleeble 1500 thermomechanical simulation device. The Gleeble, with weld variables of temperature, time to temperature, and plastic upset, was used to simulate various solid-state welding conditions.

\section{EXPERIMENTAL PROCEDURE}

Two Type 304L stainless steel sample configurations were evaluated in the study, resistance upset welded hollow cylinders and Gleeble test specimens. The hollow cylinders, having an O.D. of 2.5 in. and I.D. of $\sim 1.9 \mathrm{in}$., were welded at $85.7 \mathrm{kA}$ using a force of $45 \mathrm{ksi}$. The Gleeble samples were prepared from two $5 \mathrm{~cm}$ long, $1.5 \mathrm{~cm}$ diameter rods and were welded at $800^{\circ} \mathrm{C}, 900^{\circ} \mathrm{C}$, and $1200^{\circ} \mathrm{C}$. All Gleeble specimens received $0.5 \mathrm{~cm}$ of upset. 
Sample preparation for optical metallography and TEM analysis was performed in essentially the same manner for both sample types. Optical metallography samples were prepared to reveal the grain structure in the interface region. Standard specimen preparation techniques were used. Final etching was performed using a solution of $10 \mathrm{~g}$ oxalic acid in $100 \mathrm{ml}$ water ( $10 \%$ oxalic acid solution) at 6 volts for 3 minutes.

Specimens for TEM analysis were prepared from the upset region of each sample type. (A generalized schematic for TEM sample preparation is presented in Figure 1.) Thin slices were sectioned from an orientation normal to the weld plane. Each slice was ground to a thickness of $\sim 0.5 \mathrm{~mm}$ and subsequently etched to reveal the location of the weld interface. TEM samples, measuring $3 \mathrm{~mm}$ in diameter, were punched from the etched slices so as to contain a section of the weld interface. Samples were also punched from areas removed from the weld interface for analysis of the "base" microstructure.

A new specimen preparation technique which employed a precision dimple grinding. instrument was developed to prepare thin foils from disks containing welds. This instrument, equipped with a $\sim 0.5 \mathrm{~mm}$ wide grinding wheel, was used to preferentially remove material from a narrow region of each disk parallel to and on top of the weld interface. Grinding in this manner increased the probability that the electron transparent area produced during jet-polishing was located in the weld interface region. Jet-polishing was performed electrolytically at a potential of $\sim 15$ Vdc using a solution of $20 \%$ perchloric acid and methanol cooled to $-40^{\circ} \mathrm{C}$. TEM was performed using a Philips EM400T scanning/transmission electron microscope operating at $120 \mathrm{kV}$.

The technique for preparing thin foils did not always produce thin area at the actual weld interface. In order to determine the precise location of the interface in the polished disk, optical metallography and scanning electron microscopy (SEM) where used. Measurements taken from relevant micrographs were used to locate the interface and its spatial relationship to the electron transparent area. In cases where the interface appeared to transect the thin area, the location of the weld in TEM micrographs was confirmed by identifying common morphological features of the thin area in optical, SEM, and TEM micrographs and images. 
Several foils where the electron transparent region was not located near the weld were etched with $10 \%$ oxalic acid solution to provide additional information about the weld interface. SEM and TEM were used to characterize these foils.

\section{RESULTS AND DISCUSSION}

\section{Upset Welded Cylinders}

The microstructure at the weld interface in the upset welded cylinders is shown in .Figure 2. The dark "line" at the arrows indicates the location of the weld interface. This light micrograph also shows that a uniform grain structure is present in the weld region. TEM micrographs (e.g. Figure 3 ) showed that the grain interiors consisted of dislocationfree subgrains typical of a statically recovered microstructure. Individual dislocations were evident in the subgrain boundaries (Figure 3 ). This microstructure was different than that at $5 \mathrm{~mm}$ away from the interface (Figure 4) where the grain interiors exhibited a worked substructure, i.e., a high dislocation density, incipient dislocation cell formation, and extensive faulting.

TEM images of the weld interface (e.g. Figure 5) showed no distinct bond line was present. Grain growth was continuous across the weld interface as would be expected for a "good" solid-state weld. In fact, the only way to differentiate the location of the bond line/interface from the surrounding matrix was by the presence of a "row" of precipitates. The precipitates observed in the polished foils were generally round, ranging in diameter from 50 to $240 \mathrm{~nm}$ and spaced between 0.6 and $1.3 \mu \mathrm{m}$ apart (Figures 5 and 6$)^{*}$. EDS analysis of the precipitates in Figure $6 \mathrm{~b}$ showed $\mathrm{Si}$ and $\mathrm{Al}$ and possibly enrichment in $\mathrm{Mn}$ when compared to the austenite matrix. Electron diffraction analysis and extensive tilting experiments suggested that these precipitates were amorphous, i.e., non-crystalline.

Foils etched with $10 \%$ oxalic following TEM examination were also examined in this study. Figure 7 is an SEM micrograph of the weld interface in one of these foil samples which shows a number of precipitates. The average spacing of the precipitates in Figure 7 was

\footnotetext{
- The apparent bond line in Figures 5 and 6 may not be the original line/plane of contact between the unwelded cylinders prior to welding. However, the "row" of precipitates observed in these micrographs are located in the same position as the apparent bond line in light optical and SEM micrographs.
} 
$\sim 0.4 \mu \mathrm{m}$. The diameter of these particles was consistent with those observed in the polished foils.

TEM examination of the interface regions from the etched foils revealed the presence of a another precipitate species. The precipitates observed were partially dissolved and protruding from the surrounding austenite matrix (Figure 8). Close examination of the larger precipitates revealed that they were micro-crystalline in nature. Images (e.g., Figure 8) showed that in nearly all cases they were composed of, what appeared to be, many randomly oriented $<100$ $\mathrm{nm}$ sized "grains". EDS analysis of these composite precipitates showed they.were $\mathrm{Cr}$ and $\mathrm{Mn}$-rich and also contained $\mathrm{Si}, \mathrm{Fe}$, and $\mathrm{Ni}$. Electron diffraction patterns from these precipitates indexed consistently as a compound having the face-centered cubic crystal structure and a lattice parameter $\left(a_{0}\right)$ of $\sim 8.44 \AA$. The crystal structure and lattice parameter closely matched the spinel $\mathrm{Mn}_{1.5} \mathrm{Cr}_{1.5} \mathrm{O}_{4}$ (fcc, $\mathrm{a}_{0}=$ $8.455 \AA)$. Based on these results this precipitate species is believed to be a compositional variant of $\mathrm{Mn}_{1.5} \mathrm{Cr}_{1.5} \mathrm{O}_{4}$ with $\mathrm{Si}, \mathrm{Ni}$ and $\mathrm{Fe}$ substituting for either $\mathrm{Mn}$ and/or $\mathrm{Cr}$ in the spinel structure.

\section{Gleeble Sample $\left(1200^{\circ} \mathrm{C}\right)$}

The grain structure in the interface region of the $1200^{\circ} \mathrm{C}$ Gleeble sample is shown in Figure 9. The grains away from the interface were large, mostly equiaxed and contained annealing twins. Closer examination revealed that many annealing twins were slightly "bent" or curved indicating the grains in this region had been plastically deformed. The heavily dislocated substructure at $5 \mathrm{~mm}$ from the interface (Figure 10) is further evidence of the "worked" nature of the microstructure away from the weld interface. In contrast, the substructure at the weld interface was much finer and appeared to be heavily faulted in some regions (Figure 9). The grain structure near the interface is better shown in Figure 11. This TEM micrograph shows that the small austenite grains were nearly equiaxed and mostly dislocation free. (The intense faulting in the interface region seen in Figure 9 was not observed in the TEM micrographs.)

Similar to the upset welded cylinders, the actual weld interface in the $1200^{\circ} \mathrm{C}$ Gleeble sample was only visible in the TEM because of the presence of precipitates (Figure 12). EDS and $X$-ray microanalysis again revealed the presence of two precipitate species. Most frequently, an amorphous precipitate rich in $\mathrm{Ca}$, $\mathrm{Si}$, and $\mathrm{Al}$ was observed (Figure 13). Morphologically and chemically this phase 
appeared to be similar to the amorphous phase observed in the upset welded cylinders (Figure 6). A crystalline species was also observed in the Gleeble sample. Electron diffraction patterns from these precipitates indexed consistently as the spinel, $\mathrm{Mn}_{1.5} \mathrm{Cr}_{1.5} \mathrm{O}_{4}$, the same phase present in the upset welded cylinders (Figure 14). Both precipitate species ranged from 45 to $300 \mathrm{~nm}$ in diameter and were spaced, on average, $1.2 \mu \mathrm{m}$ apart.

Observation of $\mathrm{Mn}_{1.5} \mathrm{Cr}_{1.5} \mathrm{O}_{4}$ and the amorphous phase was not limited to the interface region in this sample material. $\mathrm{Mn}_{1.5} \mathrm{Cr}_{1.5} \mathrm{O}_{4}$ was also observed at $170 \mu \mathrm{m}$ from the weld in one thin foil and the amorphous phase was located in the bulk material at $5 . \mathrm{mm}$ from the weld in another. In general, these "internal" precipitates ranged from 1 to 3 $\mu \mathrm{m}$ in diameter, much larger in size than those precipitates observed at the interface.

In addition to $\mathrm{Mn}_{1.5} \mathrm{Cr}_{1.5} \mathrm{O}_{4}$ and the amorphous precipitates, another second phase region was observed along the interface in one thin foil (Figure 15). The diffraction patterns from this region indexed consistently as either body-centered cubic $\alpha$ Fe or $\alpha^{\prime}$ martensite. EDS showed the composition of this region was nearly identical to the adjacent matrix region which confirmed that this phase was $\alpha^{\prime}$ martensite and not $\alpha \cdot \mathrm{Fe}$. Observation of $\alpha^{\prime}$ martensite was not limited to the interface region. This phase was also observed at $170 \mu \mathrm{m}$ and $5 \mathrm{~mm}$ from the weld. Furthermore, the hexagonal (hcp) $\varepsilon$ martensite phase (Figure 16) was also observed at $5 \mathrm{~mm}$ from the interface along with $\alpha^{\prime}$ martensite in the interior of a deformation band. Both types of martensite have been observed in cold worked Type 304 stainless steel, e.g. [4], and their presence may or may not be a result of the deformation incurred during the solid-state welding process.

\section{Gleeble Samples $\left(800\right.$ and $\left.900^{\circ} \mathrm{C}\right)$}

Limited information was obtained from specimens welded at $800^{\circ} \mathrm{C}$ and $900^{\circ} \mathrm{C}$. Two short segments of weld interface were observed in different $900^{\circ} \mathrm{C}$ samples. As in the $1200^{\circ} \mathrm{C}$ Gleeble sample, a high Sicontaining amorphous phase and the crystalline phase, $\mathrm{Mn}_{1.5} \mathrm{Cr}_{1.5} \mathrm{O}_{4}$ were observed at the weld interface (Figure 17). Precipitate sizes ranged from 60 to $200 \mathrm{~nm}$. No electron transparent area formed at the weld interface in any of the $800^{\circ} \mathrm{C}$ specimens examined.

The microstructure at or within $300 \mu \mathrm{m}$ of the interface in both the $800^{\circ} \mathrm{C}$ and $900^{\circ} \mathrm{C}$ samples contained significantly more dislocations and 
dislocation cells than the other samples examined (e.g., Figure 18). The microstructure in the interface region in the $900^{\circ} \mathrm{C}$ samples was characterized by a higher free-dislocation density (when compared to the welded cylinders and $1200^{\circ} \mathrm{C}$ Gleeble sample) and the absence of subgrains. In several regions stacking faults and stacking fault bundles were observed. This microstructure was the result of the lower welding temperatures and considerable upset given these samples. In the $800^{\circ} \mathrm{C}$ samples several large amorphous precipitates (Figure 19) were observed at approximately $250 \mu \mathrm{m}$ from the weld interface (distance 'determined by light microscopy). This result is consistent with the results obtained from the $1200^{\circ} \mathrm{C}$ Gleeble sample where similar precipitates were observed at $5 \mathrm{~mm}$ from the weld interface.

\section{Qrigin of Interface Precipitates}

Similar precipitate species were found at the weld interface in both specimen types, i.e., an amorphous Si-rich phase and the crystalline phase, $\mathrm{Mn}_{1.5} \mathrm{Cr}_{1.5} \mathrm{O}_{4}$. Although the origin of the precipitates has not been determined, the reason(s) for formation are likely related to the condition of the surfaces of the unwelded parts.

Several possibilities exist to explain the presence of the precipitates. One reason may be that surface oxide(s) on the unwelded bars dissolved during welding and then re-precipitated at the "interface" as the welds cooled. Moreover, surface oxides may have only dissolved partially and/or softened at the higher welding temperatures and subsequently spheroidized (due to surface tension forces), minimizing the surface area of the remaining "oxide" particles. This scenario would explain the spherical nature of most of the precipitates at the interface. Another possibility is that lubricant used during machining of the unwelded parts became "trapped" in the near-surface layer of the material, subsequently reacting with the stainless steel matrix at the elevated welding temperatures. Another possible origin of the precipitates could be the impurity phases located within the original parts. TEM results from the Gleeble samples showed that both the amorphous phase and the $\mathrm{Mn}_{1.5} \mathrm{Cr}_{1.5} \mathrm{O}_{4}$ were present in regions removed from the weld. These precipitates were larger in size than the interface precipitates but compositionally very similar. During welding the larger near-surface precipitates may have redistributed with grain/material flow and subsequently dissolved and reprecipitated on the interface. 


\section{CONCLUSIONS}

- None of the observed solid-state welds observed via TEM had a distinct bond line or microstructural discontinuity. Grain growth was continuous across the interface.

- In contrast, the microstructure of the low temerature $\left(900^{\circ} \mathrm{C}\right)$ Gleeble sample in the vicinity of the weld interface consisted of a high free-dislocation density, stacking faults, and stacking fault bundles.

- The microstructures at the weld interface in the high temperature $\left(1200^{\circ} \mathrm{C}\right)$ Gleeble sample and the upset welded cylinders contained well-formed subgrains and a low freedislocation density.

- In all samples, the weld interfaces were visible only due to the presence of second phase particles. $\mathrm{Mn}_{1.5} \mathrm{Cr}_{1.5} \mathrm{O}_{4}$ was observed at the interface in the upset welded cylinders as well as in the $900^{\circ} \mathrm{C}$ and $1200^{\circ} \mathrm{C}$ Gleeble samples. An unknown amorphous phase . containing $\mathrm{Si}, \mathrm{Ca}$, and $\mathrm{Al}$ was also observed in all samples examined.

- $\quad \mathrm{Mn}_{1.5} \mathrm{Cr}_{1.5} \mathrm{O}_{4}$ and the amorphous phase were also present in the base microstructure as far away as $5 \mathrm{~mm}$ from the weld interface.

- Both $\alpha^{\prime}$ martensite and $\varepsilon$ martensite were observed in the $1200^{\circ} \mathrm{C}$ Gleeble sample. These phases are observed commomly in cold worked Type 304 and 304L stainless steels.

\section{FUTURE WORK}

The results of a recent study [3] indicated that the difference in fracture toughness between as-received and as-welded Type 304L stainless steel could be related to the precipitate distributions (size and number) at the weld interface. As a result of this finding, an experimental program is being developed to determine the relationship of the microstructures that develop during welding to weld properties and welding parameters. Furthermore, this study is expected to help clarify questions concerning the origin of the weld precipitates. 
Additionally, tests are being developed to determine the effect of surface condition and cleaning agents on weld quality. TEM will be used to evaluate the microstructural characteristics of the weld interfaces.

\section{ACKNOWLEDGMENTS}

I would like to thank William Kanne, Jr. and Scott West for supplying the welded samples used in this study. I am also grateful to Cindy Foreman for her help in developing and implementing the specialized specimen preparation technique used in this study. Additionally, I'd like to thank Cindy for the long hours spent at the TEM console and the resultant darkroom work that followed.

\section{REFERENCES}

1. W. R. Kanne, Jr, "Solid State Resistance Welding: A Process With Unique Advantages For Advanced Materials (U)", Proc. of the Conf. on Advanced Joining Technologies for New Materials II, American Welding Society, pp. 127-141, July 1994.

2. S. L. West, "Characterization of Type 304L Stainless Steel SolidState Closure Welds for Radioactive Waste Containment", Microstructural Science, Vol. 22, ASM International, Materials Park, $\mathrm{OH}, 1995$

3. M. J. Morgan, The Effects of Hydrogen on the Fracture Toughness Properties of Upset Welded Stainless Steels (U), WSRC-TR-95-0270, June 1995

4. P. L. Mangonon, Jr. and G. Thomas, "The Martensite Phases in 304 Stainless Steel", Met. Trans., 1970, vol. 1, pp. 1577-86.

5. D. B. Blackburn in "Electro- and Thermo- Transport in Metals \& Alloys", Symposium Proc., R. E. Hummel and H. B. Huntington, eds., TMS-AIME, 1976, pp. 20-36. 

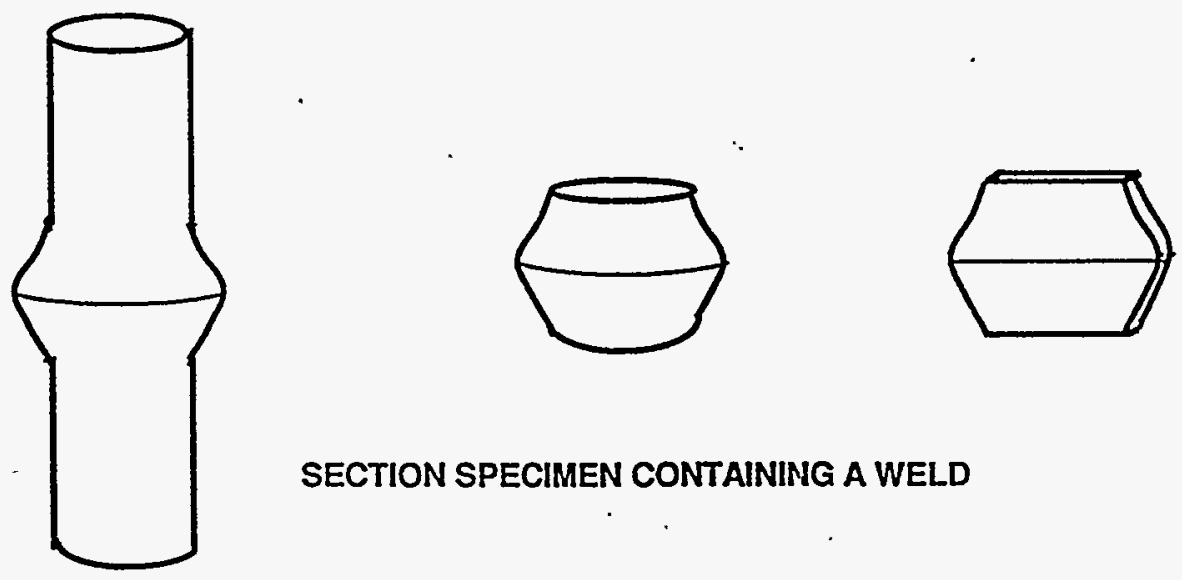

SECTION SPECIMEN CONTAINING A WELD

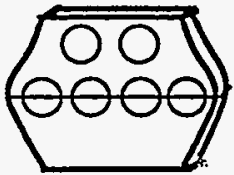

$\theta \ominus$

ETCH SAMPLE AND PUNCH 3 MM DISKS
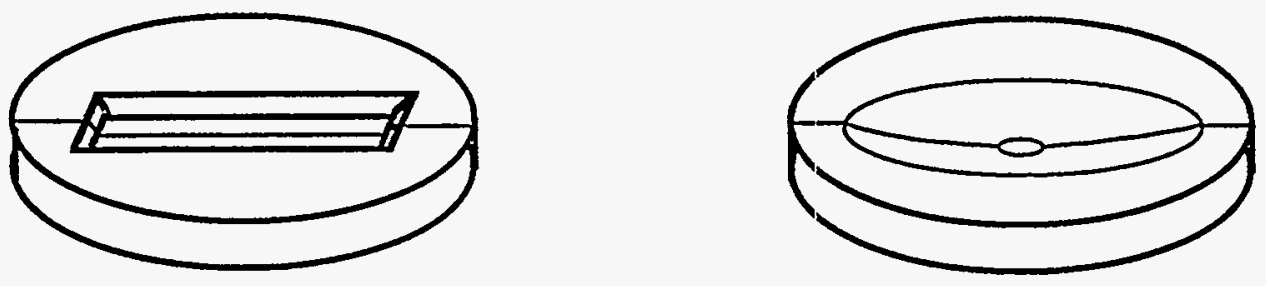

DIMPLE GRIND PARALLEL TO WELD

ELECTROPOLISH

FIGURE 1. Schematic diagram illustrating TEM specimen preparation. Thin sections containing the weld interface were sliced from each sample. Disks were punched and dimple ground along the weld interface prior to electropolishing. 


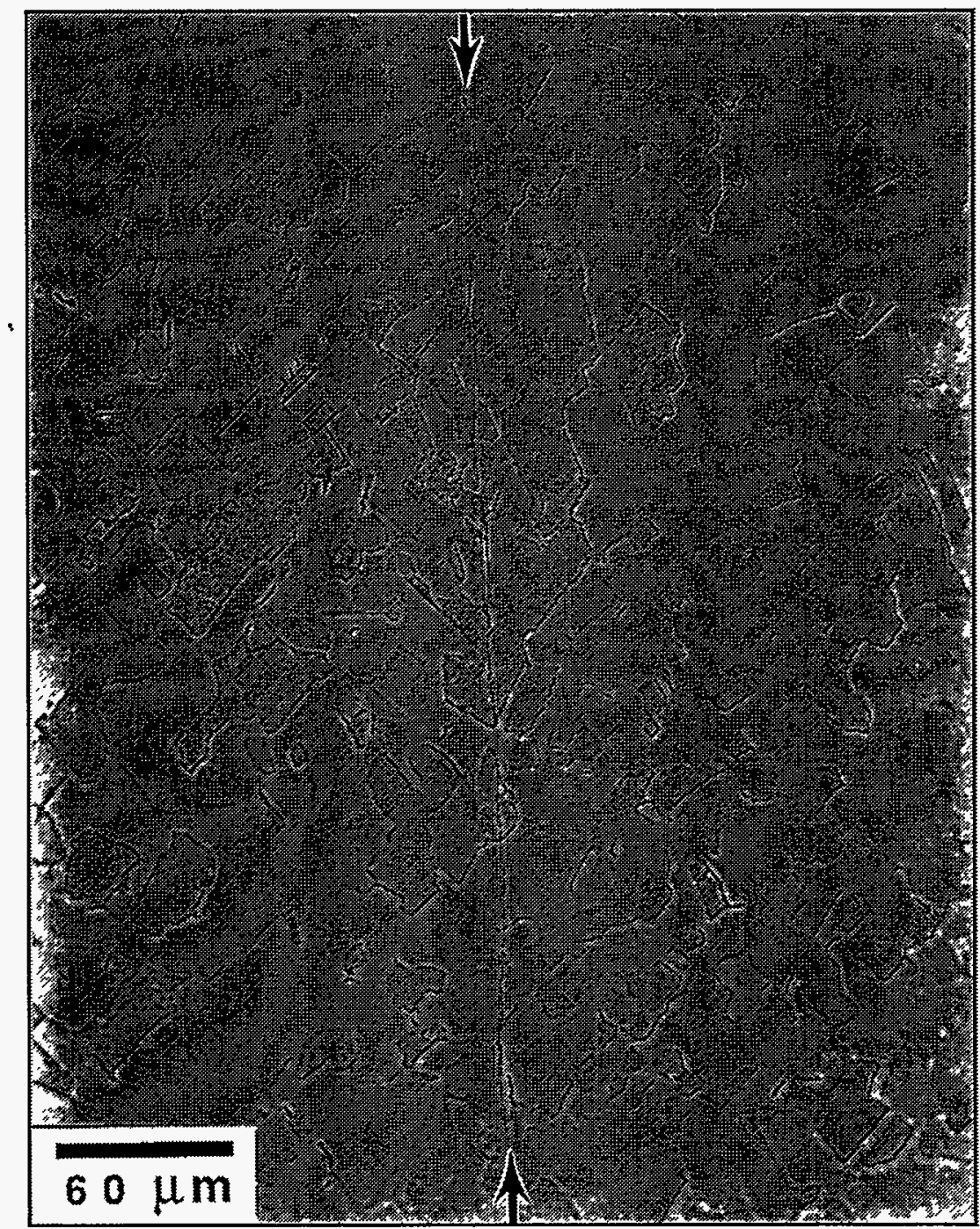

FIGURE 2. Light micrograph showing weld interface and adjacent grain structure in the upset welded cylinders. 


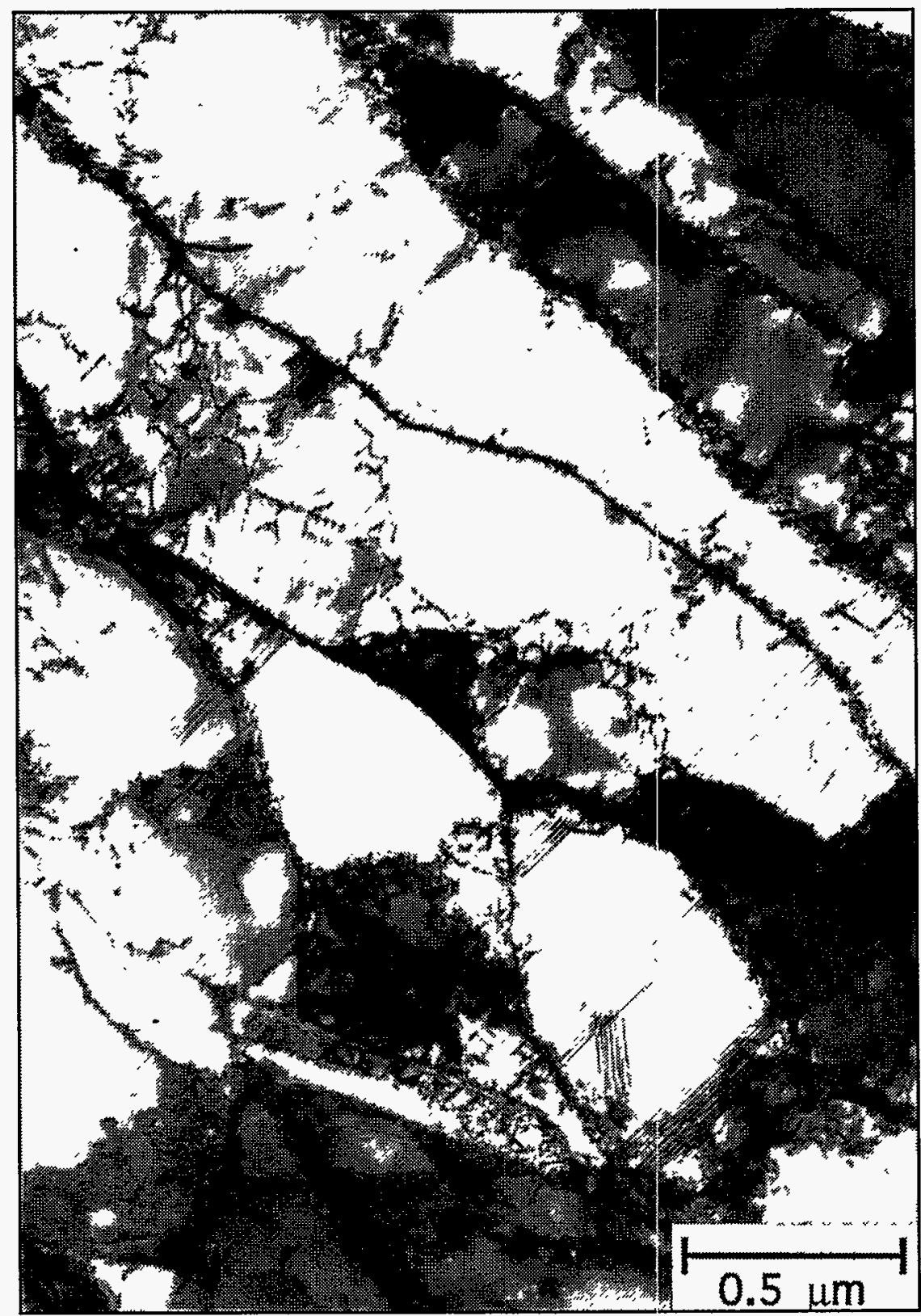

FIGURE 3. Subgrain structure immediately adjacent to weld interface in the upset welded cylinders. 


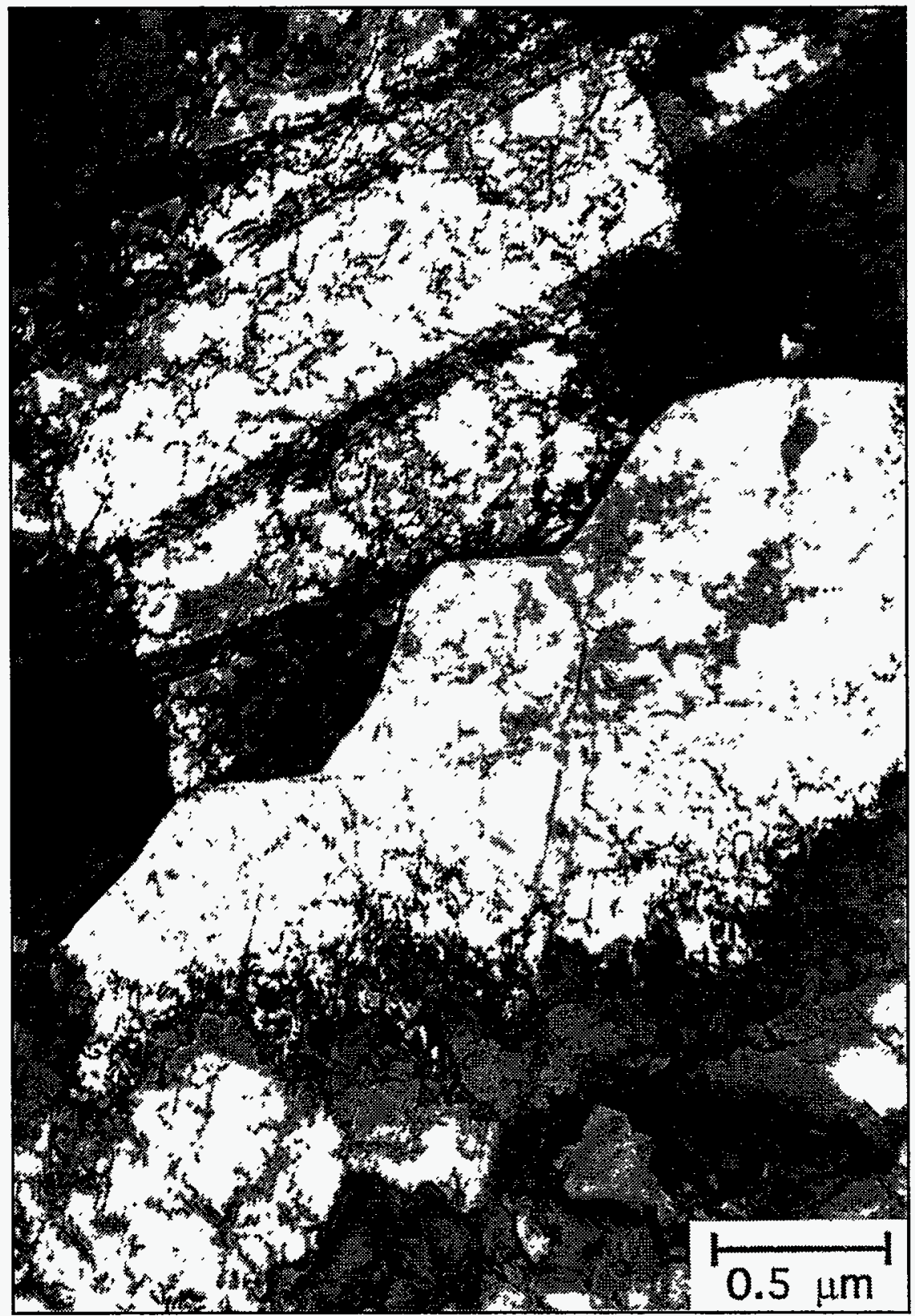

FIGURE 4. Microstructure of upset welded cylinders at approximately $5 \mathrm{~mm}$ from weld interface. 


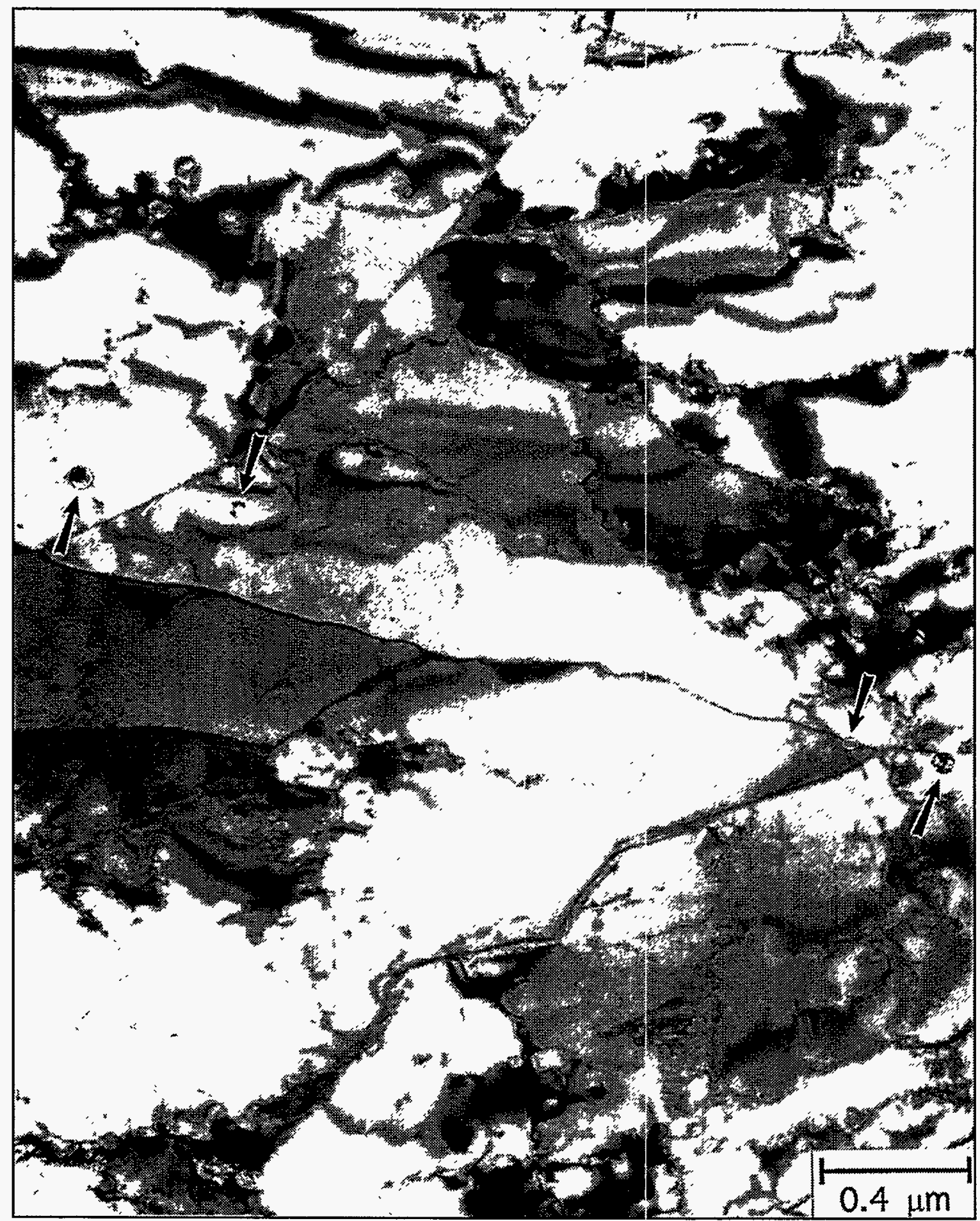

FIGURE 5. Weld interface in the upset welded cylinders. Precipitates (at arrows) mark the position of the interface. 

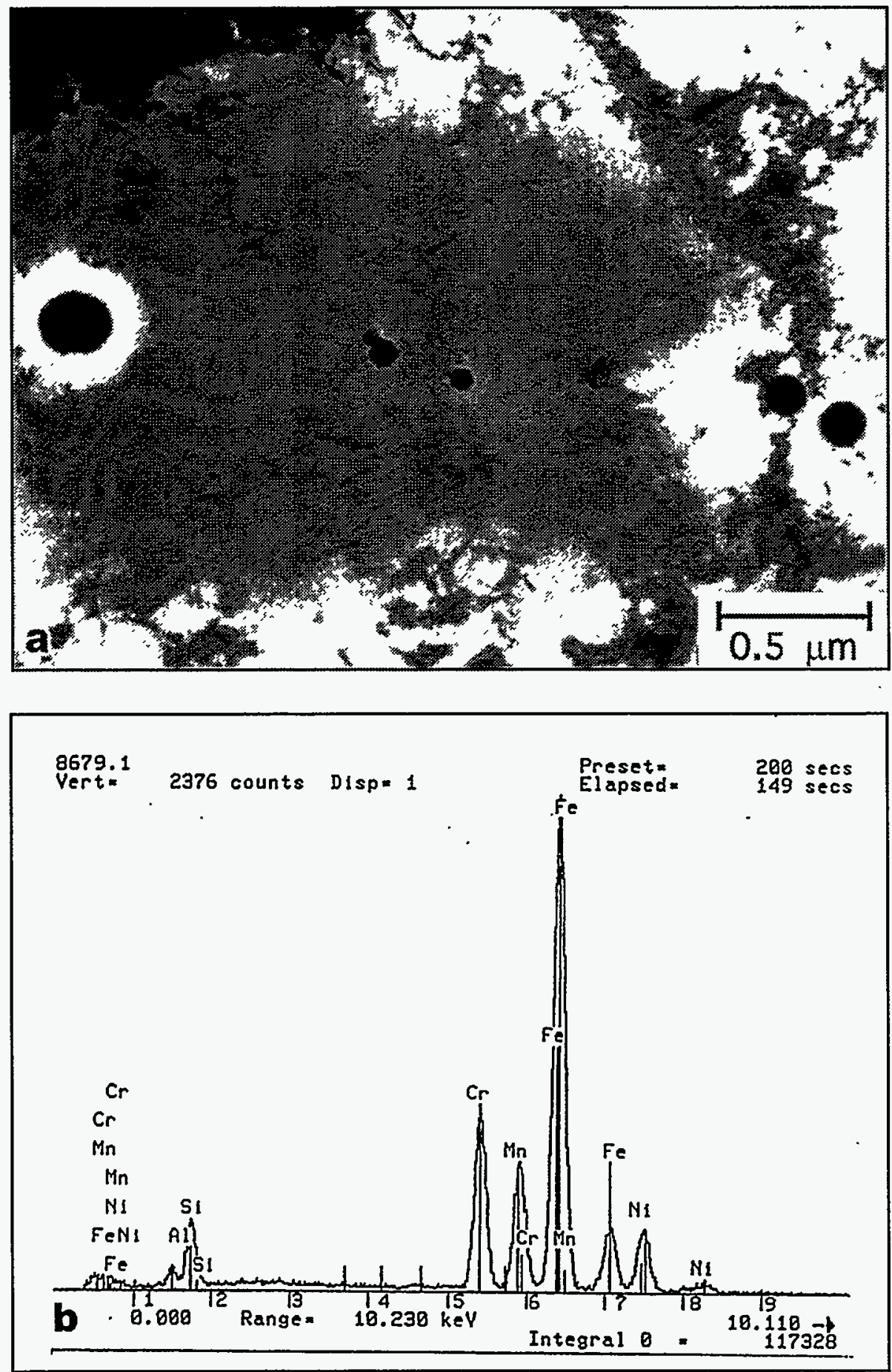

FIGURE 6. Amorphous $\mathrm{Si}, \mathrm{Al}$, and Mn-rich precipitates on the weld interface in the upset welded cylinders. (a) bright field micrograph and (b) x-ray spectrum. Note: The $\mathrm{Fe}, \mathrm{Ni}$, and $\mathrm{Cr}$ peaks arise mainly from the stainless steel base material. 


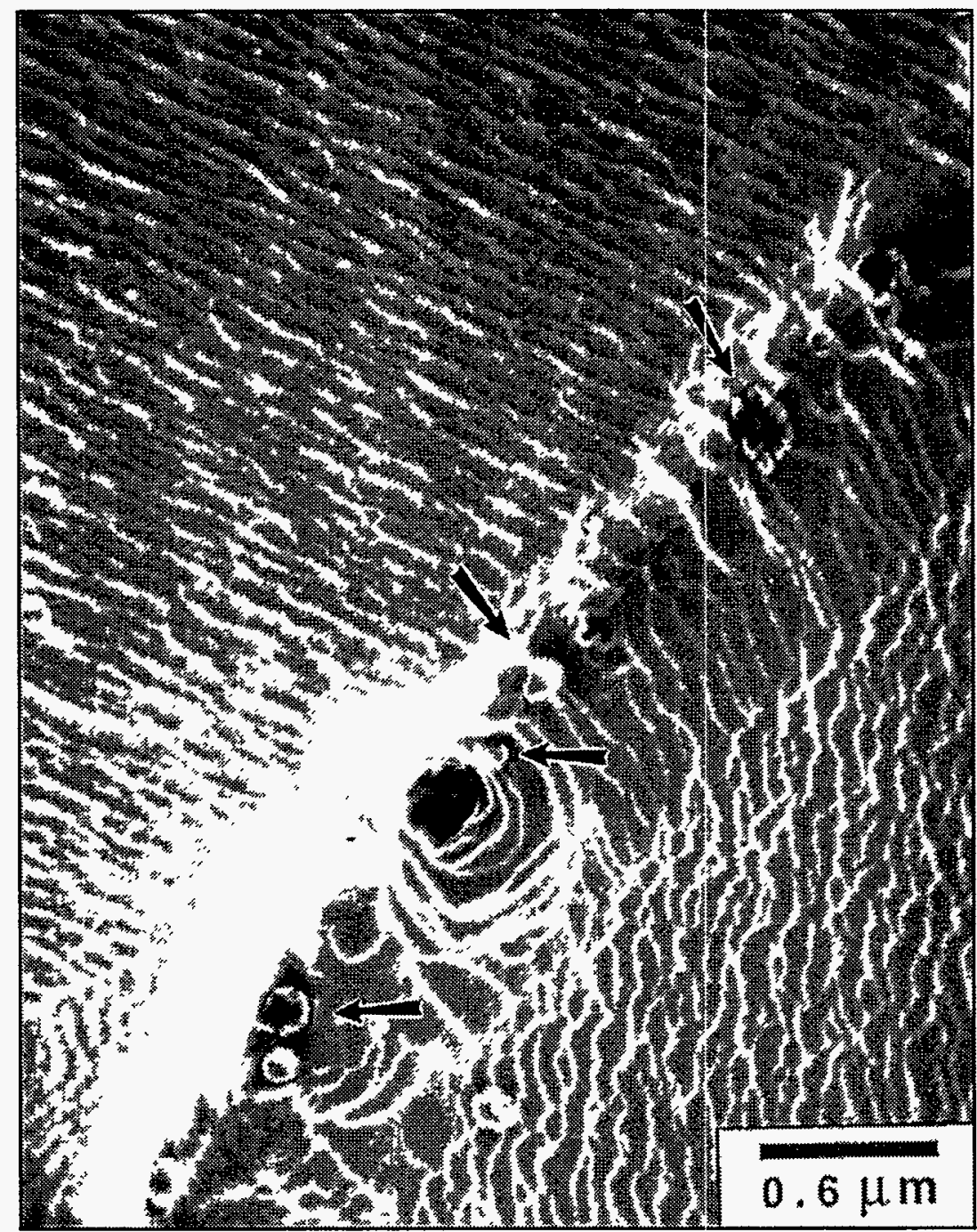

FIGURE 7. SEM image from an etched, upset welded cylinder sample which shows numerous precipitates on the weld interface. 

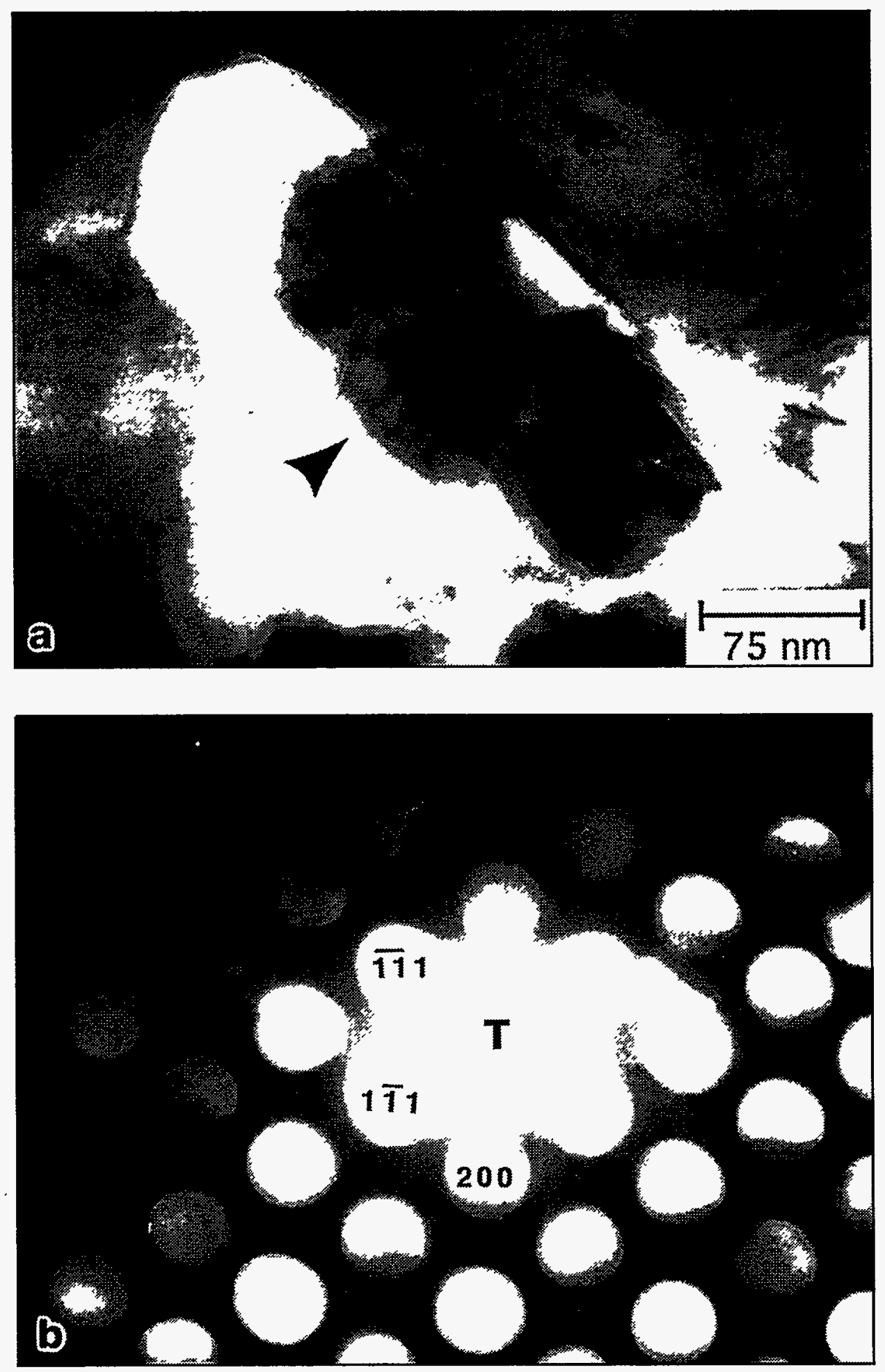

FIGURE 8. Micro-crystalline precipitate, identified as the spinel $\mathrm{Mn}_{1.5} \mathrm{Cr}_{1.5} \mathrm{O}_{4}$, on the weld interface in the upset welded cylinders: (a) bright field micrograph and (b) [011] fcc electron diffraction pattern. 


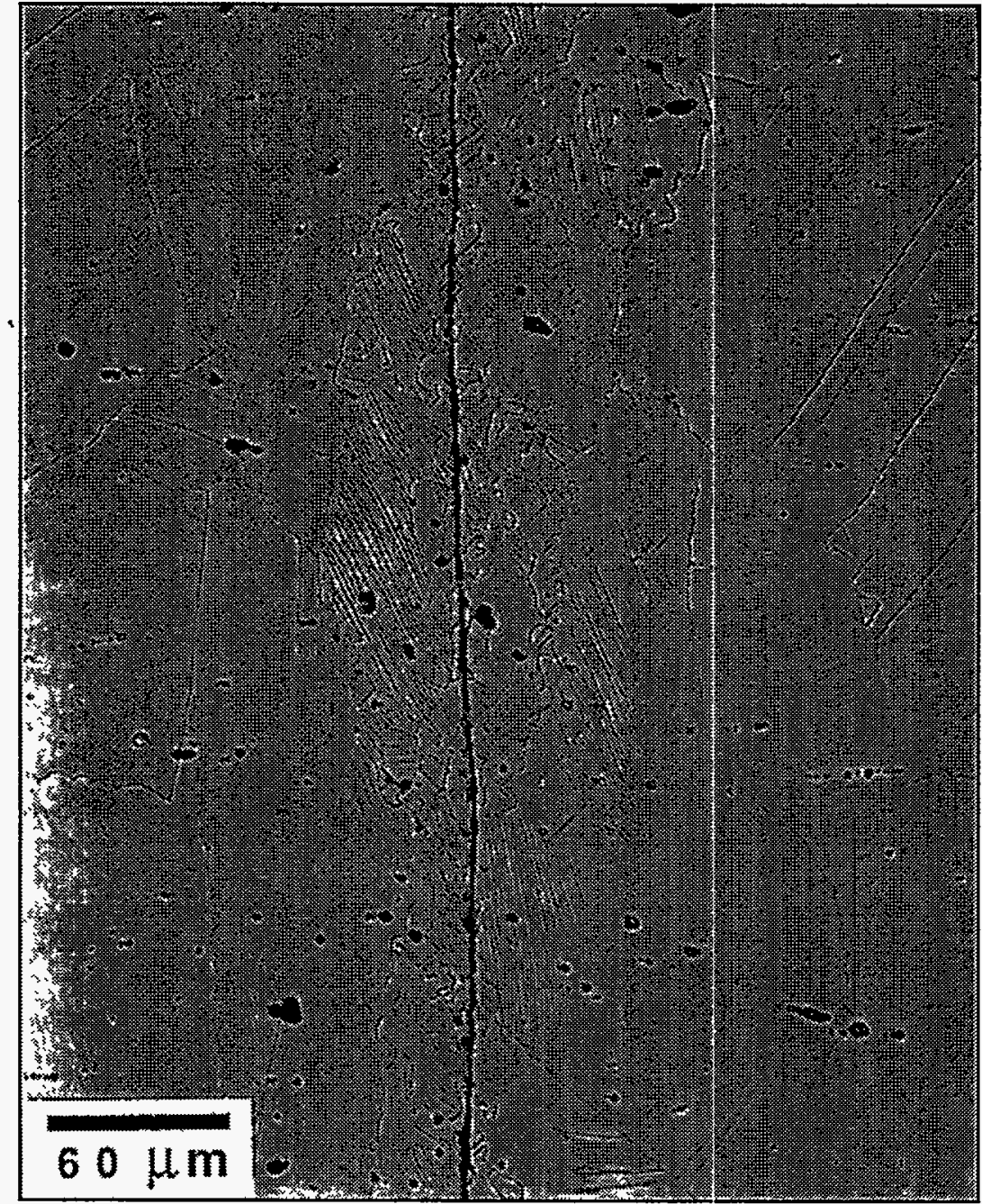

FIGURE 9. Grain structure in the interface region showing fine grains and some faulting immediately adjacent to the weld interface $\left(1200^{\circ} \mathrm{C}\right.$ Gleeble sample). 


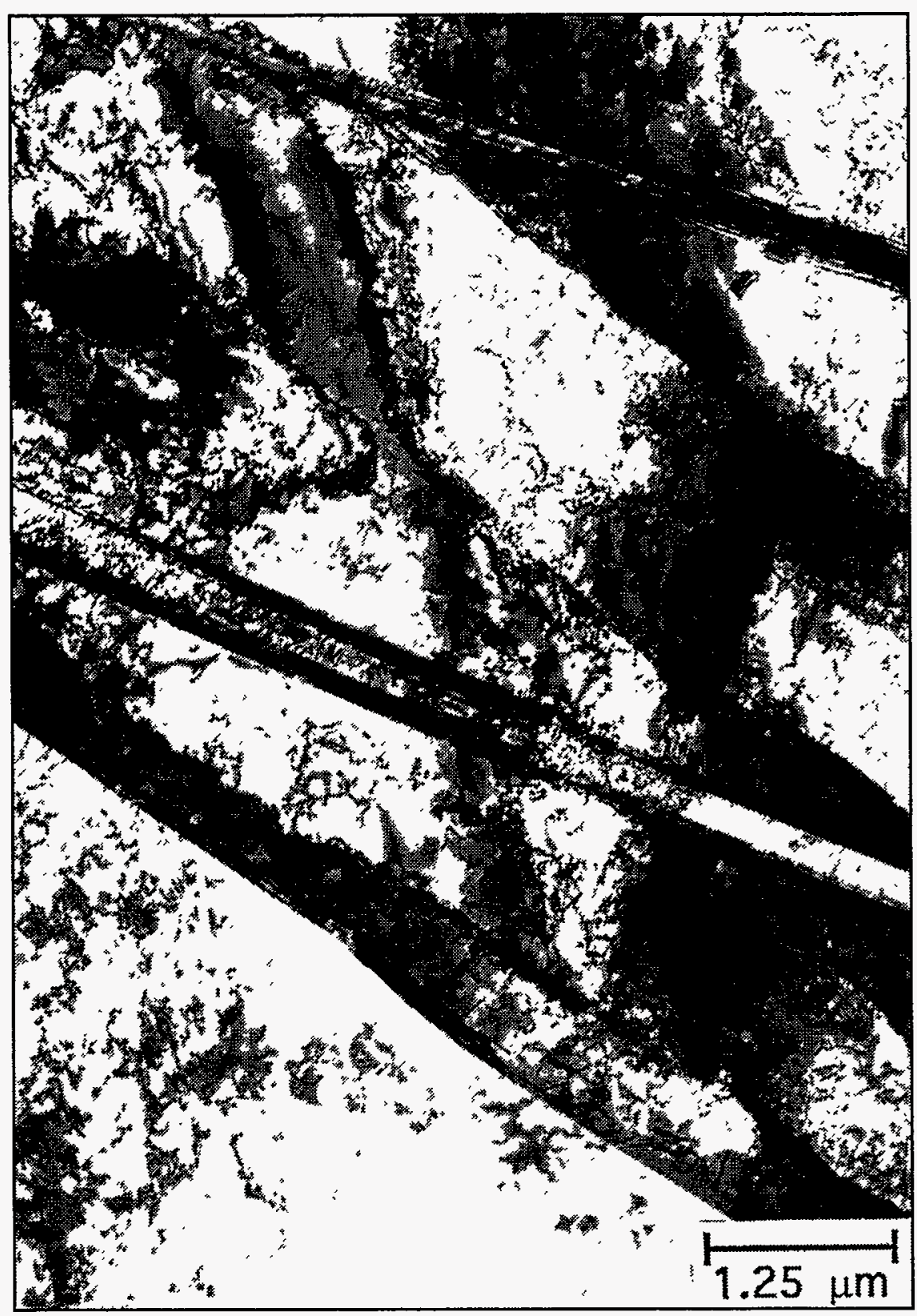

FIGURE 10. Base microstructure at $5 \mathrm{~mm}$ from the weld interface $\left(1200^{\circ} \mathrm{C}\right.$ Gleeble sample). 


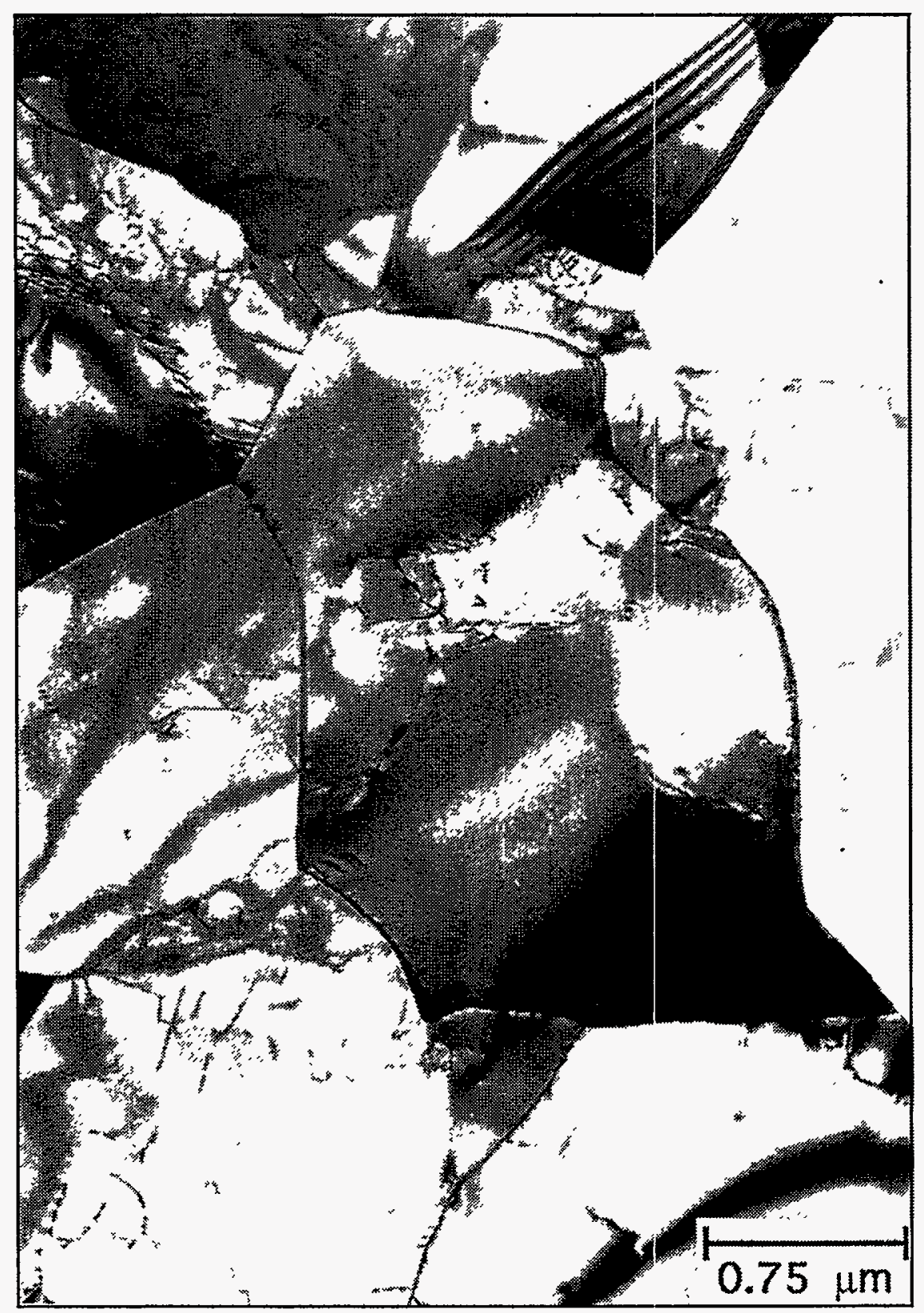

FIGURE 11. Microstructure near the weld interface $\left(1200^{\circ} \mathrm{C}\right.$ Gleeble sample). 


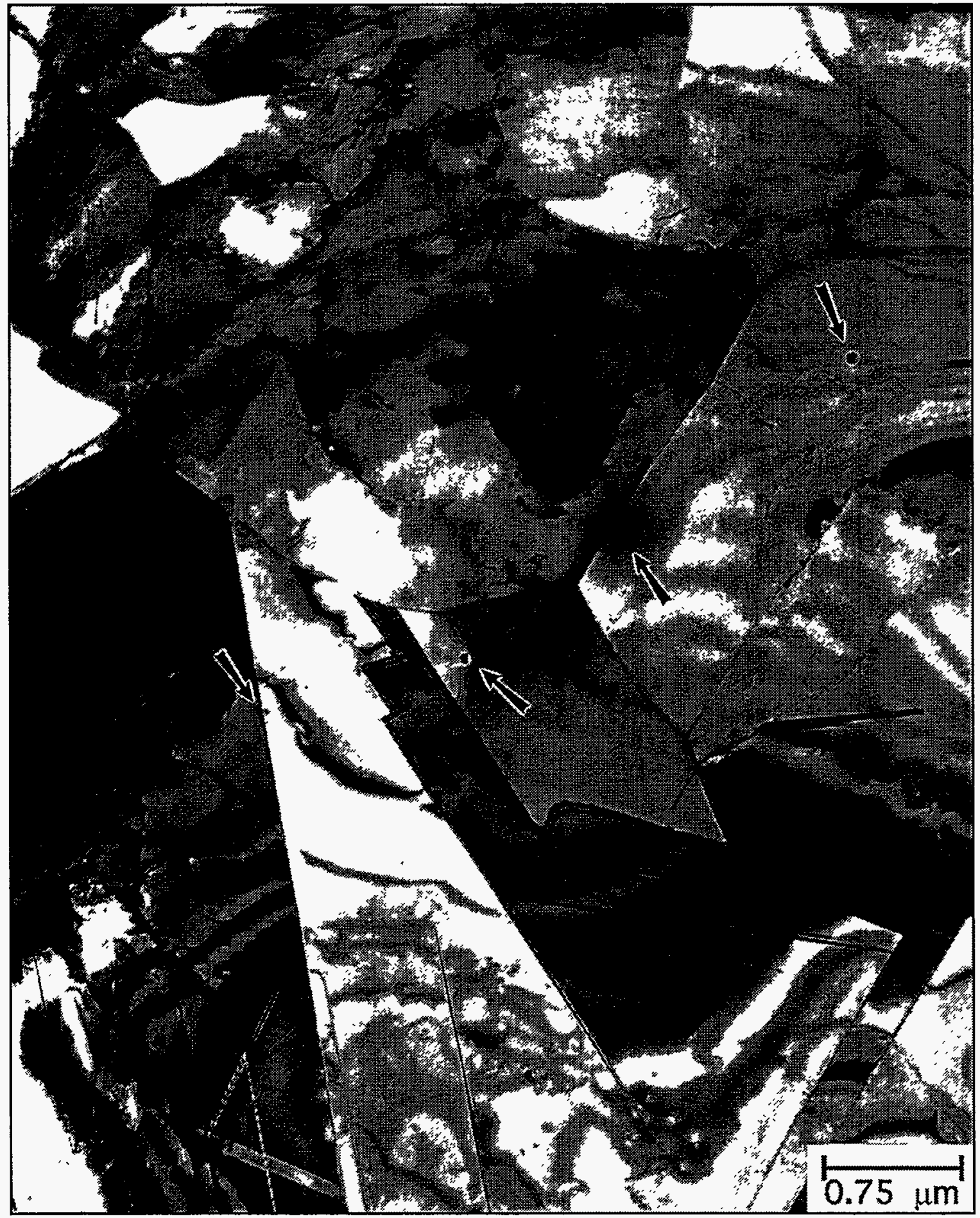

FIGURE 12. Precipitates (at arrows) on the weld interface ( $1200^{\circ} \mathrm{C}$ Gleeble sample). 

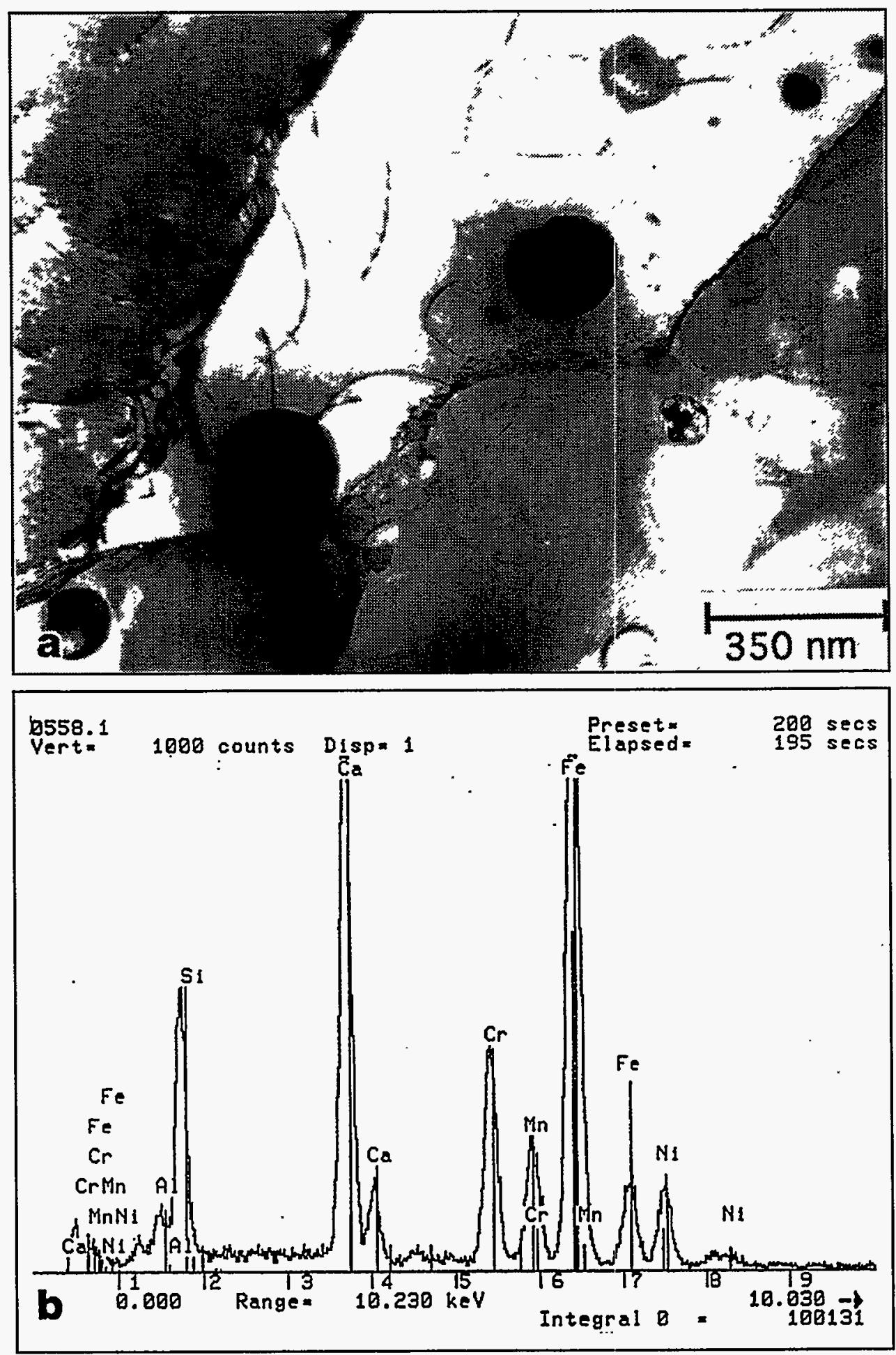

FIGURE 13. Si and Ca-containing amorphous precipitates on the weld interface $\left(1200^{\circ} \mathrm{C}\right.$ Gleeble sample). (a) bright field micrograph and (b) x-ray spectrum. 

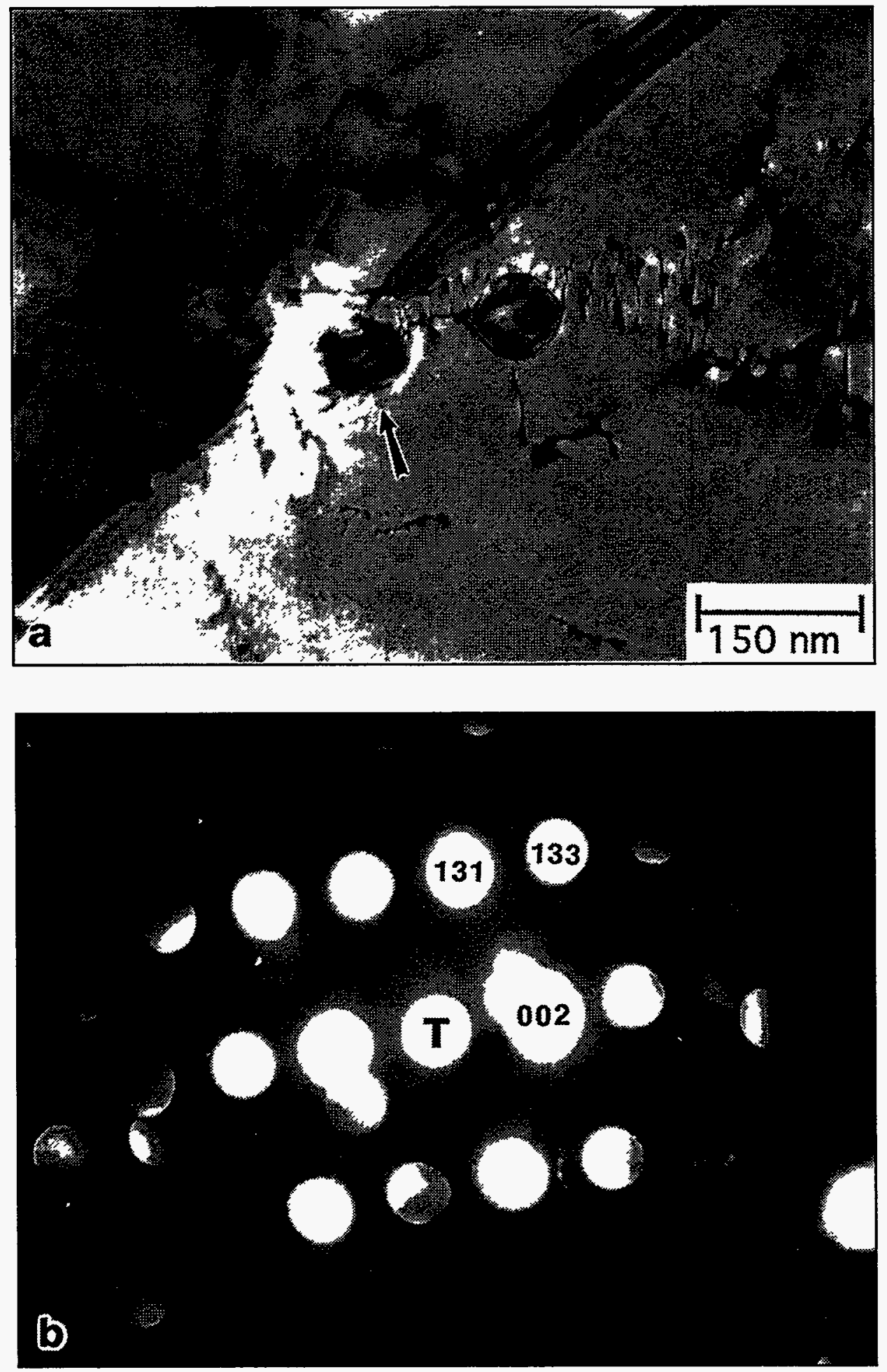

FIGURE 14. $\mathrm{Mn}_{1.5} \mathrm{Cr}_{1.5} \mathrm{O}_{4}$ precipitates on the weld interface $\left(1200^{\circ} \mathrm{C}\right.$ Gleeble sample). (a) bright field micrograph and (b) [ $\overline{3} 10]$ fcc electron diffraction pattern. 


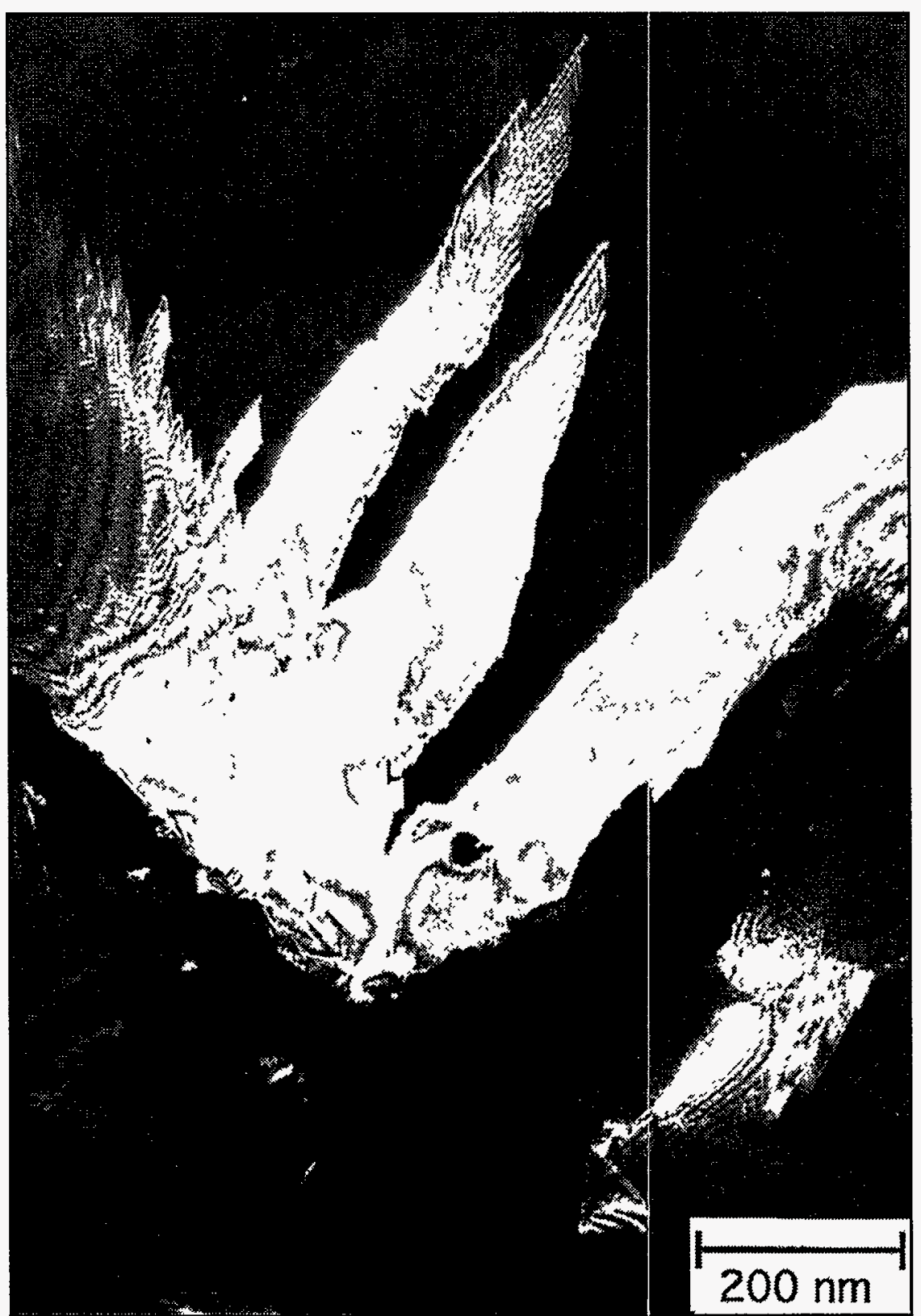

FIGURE 15. Centered-dark field micrograph of body-centered cubic $\alpha^{\prime}$ martensite at the weld interface $\left(1200^{\circ} \mathrm{C}\right.$. Gleeble sample). Image formed by using an $\alpha^{\prime}$ reflection. 

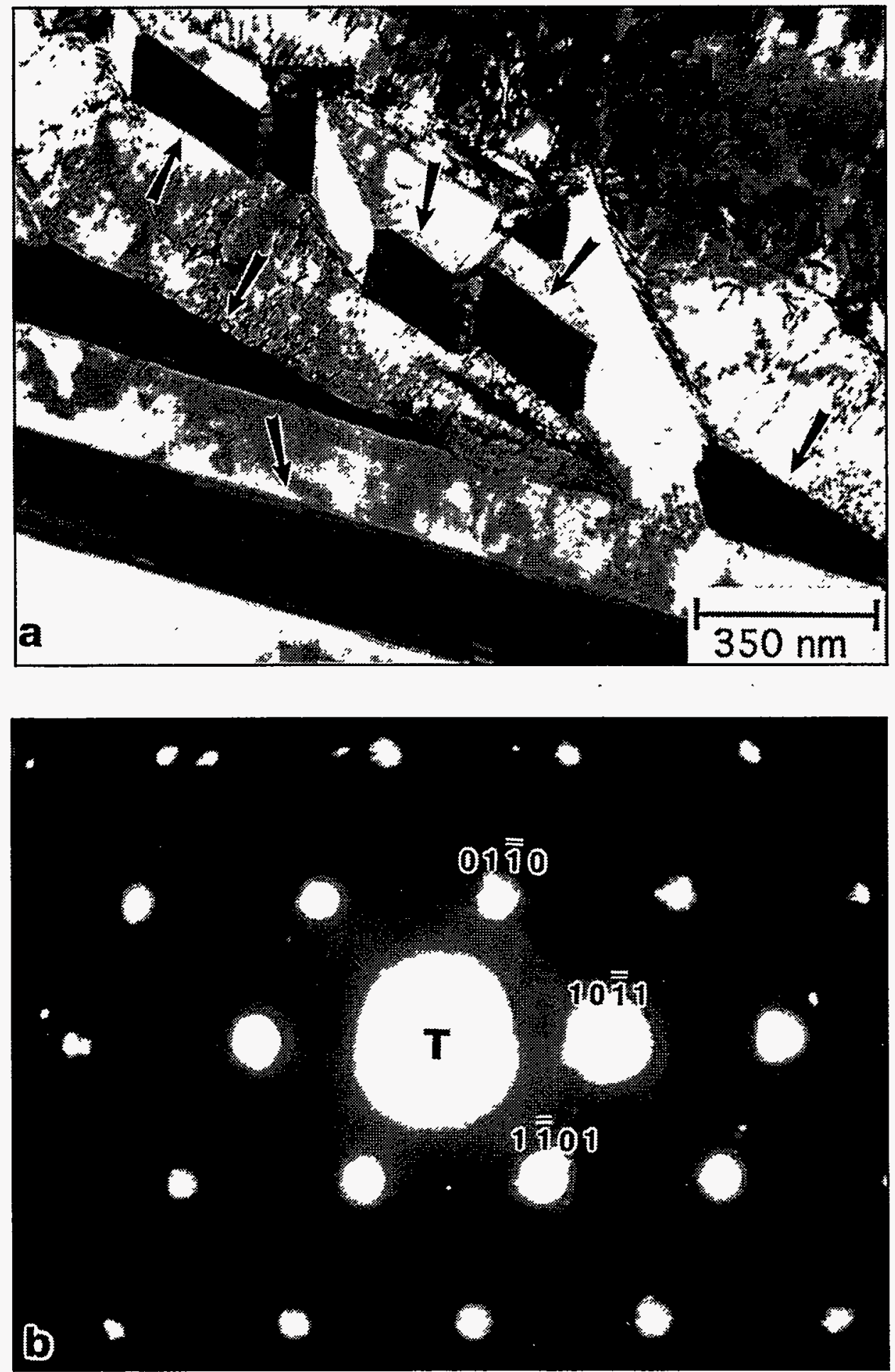

FIGURE 16. Hexagonal $\varepsilon$ martensite at $5 \mathrm{~mm}$ from the weld interface $\left(1200^{\circ} \mathrm{C}\right.$ Gleeble sample). (a) bright field micrograph and (b) [2113] fcc electron diffraction pattern. 


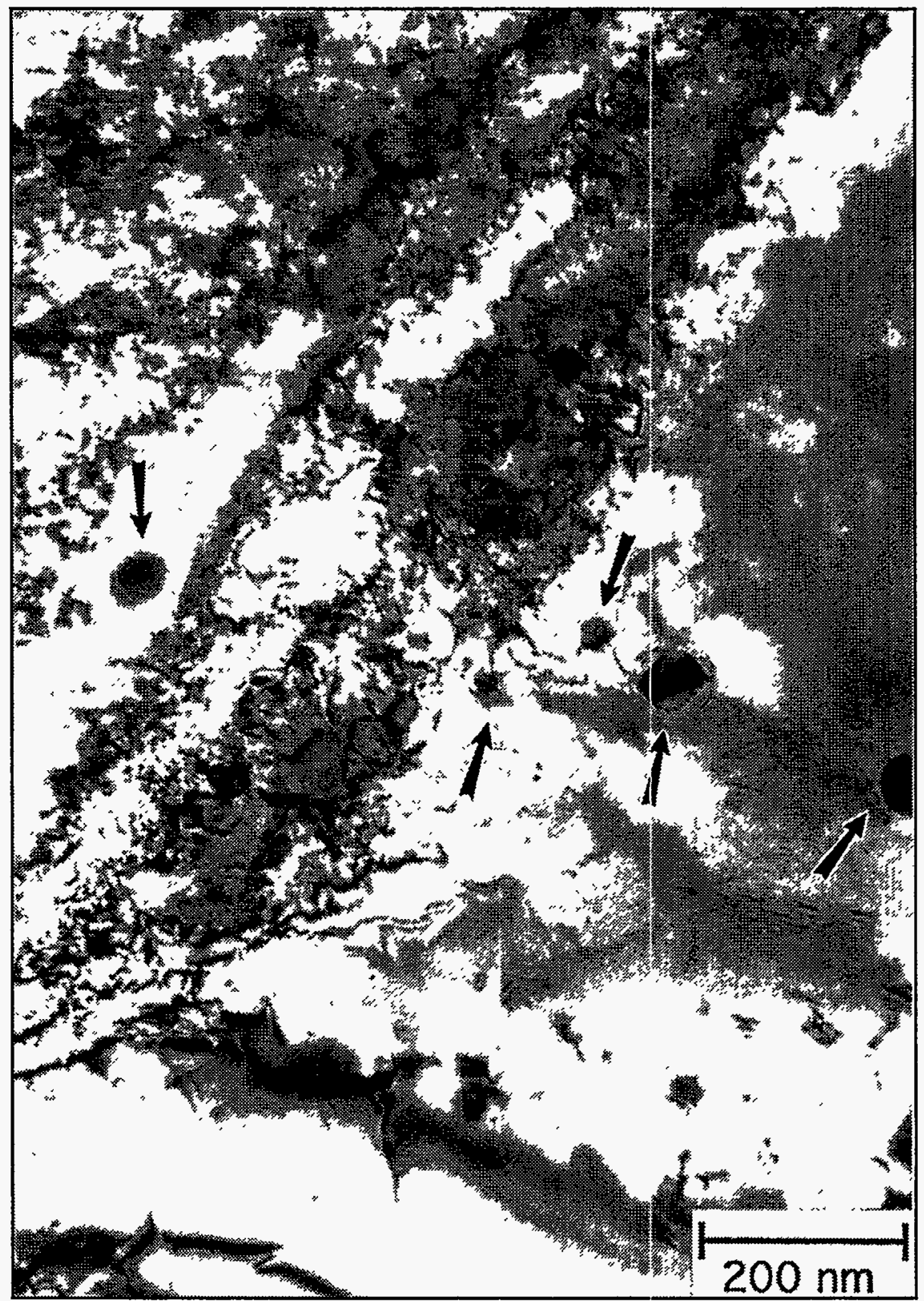

FIGURE 17. $\mathrm{Mn}_{1.5} \mathrm{Cr}_{1.5} \mathrm{O}_{4}$ and amorphous precipitates on the weld interface $\left(900^{\circ} \mathrm{C}\right.$ Gleeble sample). 

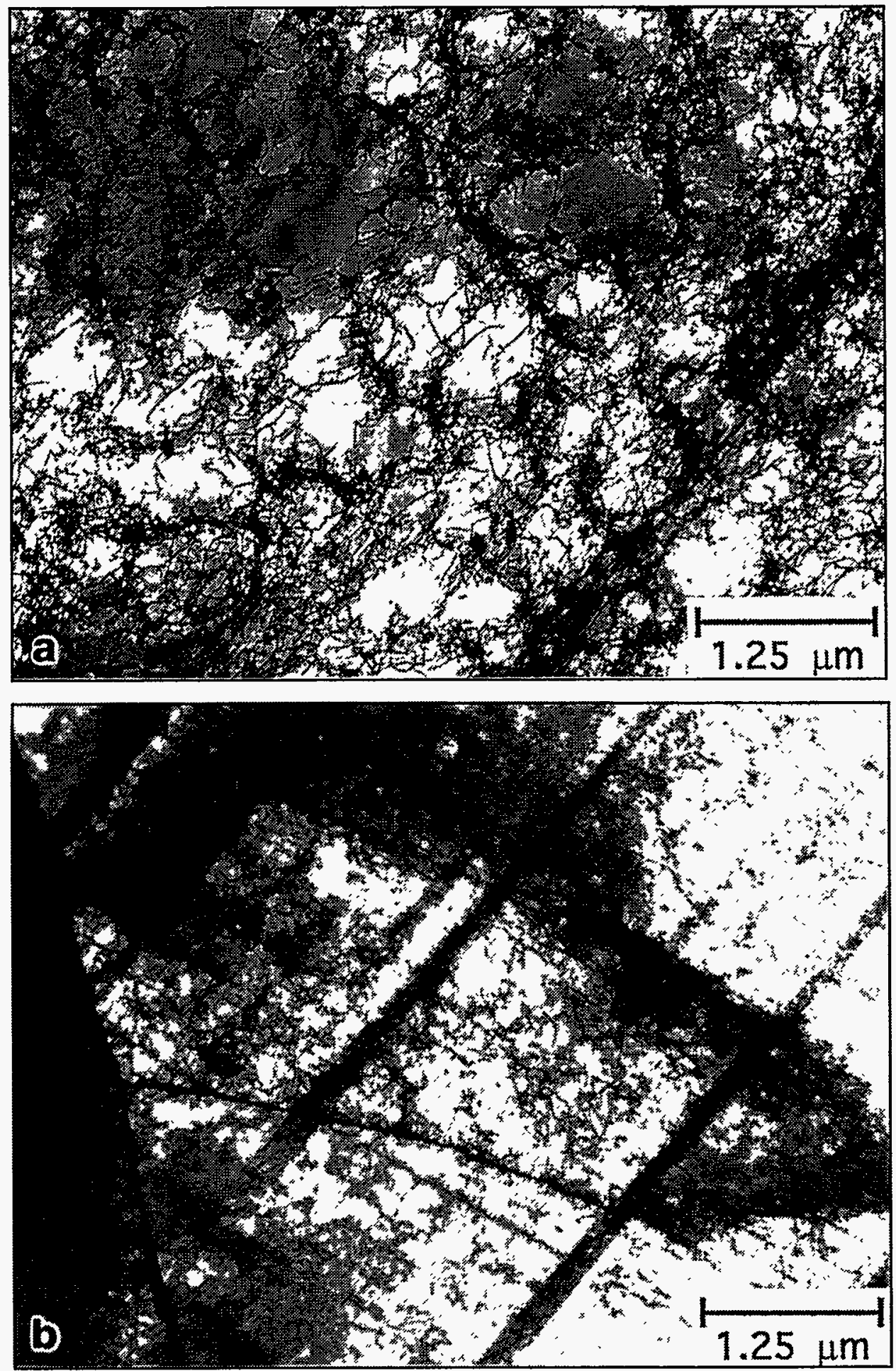

FIGURE 18. Microstructure of the $800^{\circ} \mathrm{C}$ and $900^{\circ} \mathrm{C}$ Gleeble specimens in the near-weld region. (a) dislocation cells $\left(800^{\circ} \mathrm{C}\right)$ (b) high freedislocation density and stacking faults $\left(900^{\circ} \mathrm{C}\right)$ 

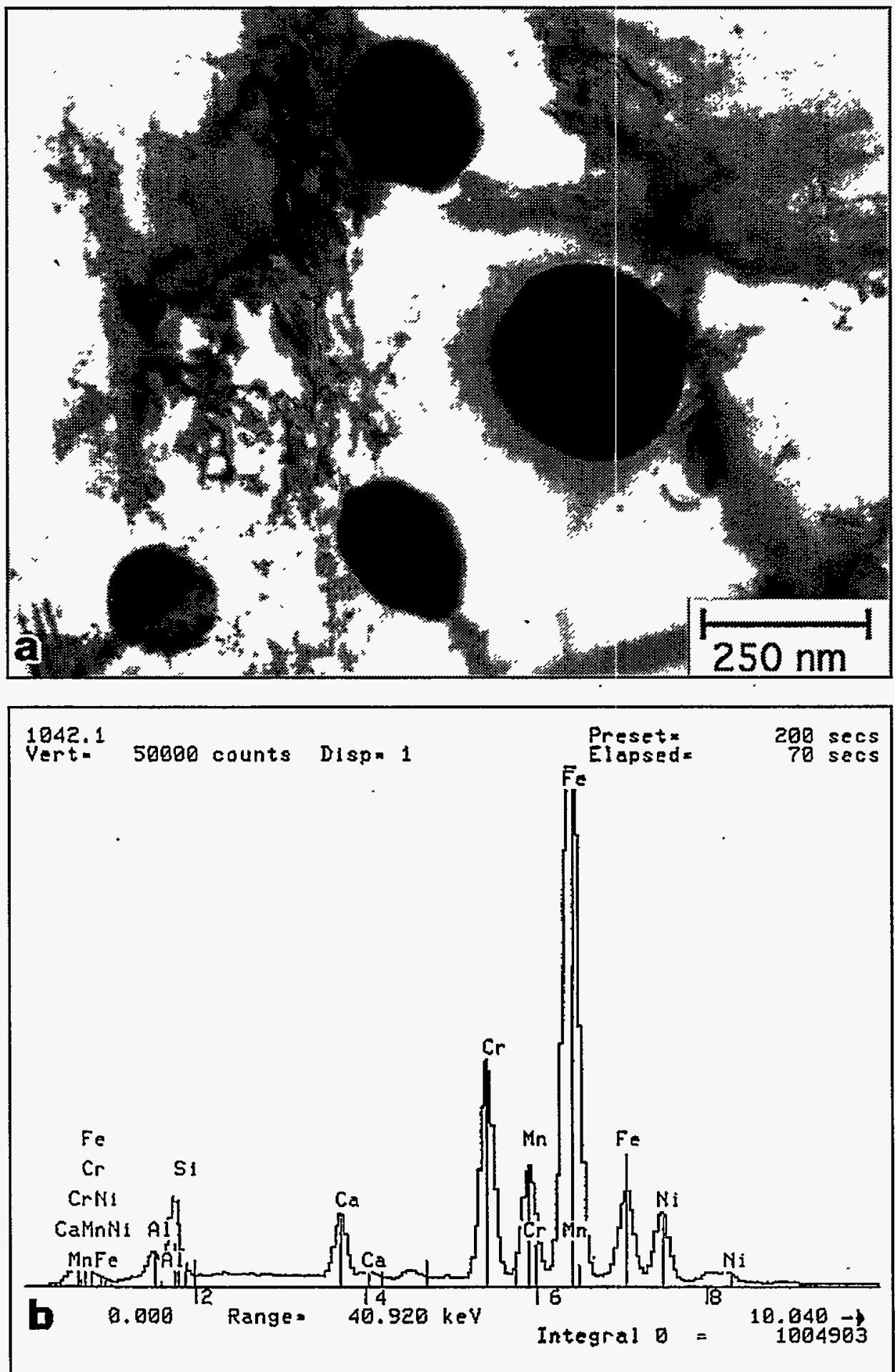

FIGURE 19. Amorphous precipitates located at approximately $250 \mu \mathrm{m}$ from the weld interface $\left(800^{\circ} \mathrm{C}\right.$ Gleeble sample). (a) bright field micrograph and (b) $x$-ray spectrum. 